\title{
The Problems of Activation of Creative Potential of a Journalist
}

\author{
Almatay Mergenbaevna Zhussupova ${ }^{1}$ \\ ${ }^{1}$ A. Baitursynov Kostanay State University, Kazaknstan \\ Correspondence: Almatay Mergenbaevna Zhussupova, Baitursynov St., 47, Kostanay, 110000, Kazakhstan.
}

Received: November 6, 2014

Accepted: December 31, 2014 Online Published: March 20, 2015

doi:10.5539/ass.v11n8p133

URL: http://dx.doi.org/10.5539/ass.v11n8p133

\begin{abstract}
Creative television management as practice of directing informative activity of a group of people is aimed at motivating for realisation of creative tasks by means of technological development of creation of spectacular informative opinion journalism. On the other hand, management of modern regional television is not limited to creative tasks and ideas - it exists on basic principles of business and rules of civilised business organisation.

As a system reflecting the result of the influence of internal and external factors on informative activity of a television and radio broadcasting channel, proper management is able to facilitate the process of identification of television with all the rest social and economic space of the region and influence competitiveness of the information environment.
\end{abstract}

Keywords: media management, competition, rating, television, information, communication study

\section{Introduction}

As a system reflecting the result of the influence of internal and external factors on informative activity of a TV and radio broadcasting channel, proper management is able to facilitate the process of identification of television with all the rest social and economic space of the region and influence competitiveness of the information environment (Akhmetova, 2000). As a result of collective analysis of the activity of regional television studios, Kazakhstan and foreign sources in the field of management of the mass media, the pre-conditions of functional-structural and content transformations in TV have been defined. Constantly growing competition on information market causes the need of introduction of media management techniques in the management of creative organisations; journalist work teams (Vartanova, 2003). Consequently, professional media managers, directors with qualification in management (Grayson \& O'Dell, 2001), who know the theory of journalism, communication, management, theory of economics sociology, conflict study, and legal foundation of the media activity should be involved in media management. Often, managerial functions are performed intuitively, due to inherent organisational abilities and qualities.

Analysis of the personnel composition of TV studios confirms that regional TV journalists rarely connect their creative work with the prospects of the development of the home TV and Radio Company; they often see the organisation as a stepping stone for professional perfection and personal growth. Young journalists collect experience and find a position in larger channels when they are offered best professional and material perspectives. There is nothing reprehensible in this, but young specialists should understand and see the perspective of their creative work in their work team.

Among the problems of programming, the most important one is the deficiency of author's projects, shortage of journalists able to create interesting programmes in two languages. Meanwhile, observations show that new peculiar programmes in Kazakh appear on state television and there is deficiency of interesting projects in Russian; on commercial TV the situation is vice versa.

Analysis shows that successful functioning and further development of regional TV companies on basis of financial independency, due to advertising profits is possible under definite factors. Local studios are developing depending on the state of local economy, small and medium business, and advertising market. Television as a sphere depending on other spheres and existing largely due to advertising profits cannot develop faster than other spheres of local economy. 


\section{Results}

\subsection{Modeling of Effective Media Management in Television}

During the analysis of the activity of regional companies, the following transformations have been determined: value paradigms of an organisation are directly connected with planning and making basic decisions; the aim, strategy and detailed plan of actions have been defined; the budget is being worked out; practice of programming of the air of a television channel taking into account viewers' interests. Selection, hiring and training of the workers of editorial team are carried out; study of brand new information technology; a clear concept of the influence of competition mechanism, marketing of publicist information, monitoring, changes taking place in the environment of consumers of information and advertisers on the media business has been stated. Encouraging innovation in journalism based online experts define as news spreads "the myth of interactivity" (Domingo, 2008, p. 680), which is currently the industry reached a key phase of experimentation. Live "blossomed" in order to attract the attention of more and more (Barnhurst, 2013).

It has been found out that the development of the mass media, including television, as transformed models of media business will proceed under the influence of innovative technology of information management that corrects internal editorial relationships and professional skills of a journalist. In this work, the mass media, their regional prototypes will be considered as corporative institutions that carry fresh content in the activity of journalist and subjects of information market. The results of marketing research conducted in Kostanay show a high level of interest of population in local programmes of TV news. On the basis of this, the research authors are confident that human resources in modern business and creative organisations become one of the chief signs defining the effectiveness, competitiveness, quality of the implemented public functions.

Social security of a journalist does not only mean setting a high minimum subsistence income, timely salary payments. For a hired employee, that journalists usually are, a painter, a director, it is important to create in conditions that would protect them from "negative influence of market", encourage the development of professional mastery and feeling of social security. The specific character of creative activity requires inclusion of editorial team of managers among specialists that have a direct relation to information practice. In such complex structured multifunctional organisations that television is, knowledge of management theory, human psychology, journalism sociology and practice of information activity might lead to the best interaction of the team members. The director who knows the specific character of their basic professional "kitchen" will bring success to the team as a business organisation (Scherbina, 2003).

\subsection{Identified Trends}

As a system reflecting the result of the influence of internal and external factors on informative activity of a TV and radio broadcasting channel, proper management is able to facilitate the process of identification of television with all the rest social and economic space of the region and influence competitiveness of the information environment. As a result of collective analysis of the activity of regional television studios, Kazakhstan and foreign sources in the field of management of the mass media, the pre-conditions of functional-structural and content transformations in TV have been defined. Basically, it is expressed in the following:

1) Constantly growing competition on information market causes the need of introduction of media management techniques in the management of creative organisations, journalist work teams. Consequently, professional media managers, directors with qualification in management, who know the theory of journalism, communication, management, theory of economics sociology, conflict study, and legal foundation of the media activity, should be involved in media management. Often, managerial functions are performed intuitively, due to inherent organisational abilities and qualities.

2) Analysis of the personnel composition of TV studios confirms that regional TV journalists rarely connect their creative work with the prospects of the development of the home TV and Radio Company; they often see the organisation as a stepping stone for professional perfection and personal growth. Young journalists collect experience and find a position in larger channels when they are offered best professional and material perspectives.

There is nothing reprehensible in this, but young specialists should understand and see the perspective of their creative work in their work team. We must admit that these social conditions when incompatible social, communicative conditions for the development of society, the media on whole cannot be free, fair and objective. The media cannot, but journalists can be (Dzyaloshinsky, 2014)

3) Among the problems of programming, the most important one is the deficiency of author's projects, shortage of journalists able to create interesting programmes in two languages. Meanwhile, observations show that new 
peculiar programmes in Kazakh appear on state television and there is deficiency of interesting projects in Russian; on commercial TV the situation is vice versa.

4) Analysis shows that successful functioning and further development of regional TV companies on basis of financial independency, due to advertising profits is possible under definite factors. Local studios are developing depending on the state of local economy, small and medium business, and advertising market. Television as a sphere depending on other spheres and existing largely due to advertising profits cannot develop faster than other spheres of local economy.

5) Technical support of regional television studios depends on the interest of the founders and owners in the activity of the media, on how ready they are for creation of profitable and competitive TV. For instance, technological support of TV and radio company "Alau" (Kostanay) and the support by the regional monopolist of grain business LLC "Ivolga-holding".

6) An important tool in motivation of journalist creativity, growth of professional career might be marketing. For example, programmes of private TV specialised in concrete themes and genres are distinguished by special stylistics, form and content of journalist materials, for example, programme "Overtime" (TRC "Alau"). This experience suggests the thought of another problem, which provides an analysis of why the "women do not appear in the news, they are often in stories about their personal lives, sex is most interesting about them and not their potential or previous experience as a serious political (business partners) players". But this is a topic for another study (Ross et al., 2013).

\subsection{Solutions to the Problem}

In the experience of TV and radio broadcasting organisations, there are some productive forms of activation of creative activity of a journalist that are widespread for increasing the rating of the channel, programmes and shows, journalists. For instance:

- Organisation of meetings with foreign public figures, innovators and experts, celebrities in editors offices;

- Invitation of experts to thematic briefings with publication reviews that consider the content, genre accomplishment, publicistic character, design and make-up of programmes;

- Organisation of creative mentoring of experienced journalists over young ones;

- Development of personal creative plans by journalists, discussion of their progress, etc.;

- Participation in various creative competitions that encourage journalists to search for new approaches and ways of improving journalist creativity.

These popular models of increasing the interest to local television can often be linked to certain creative people, journalists who often do not stay long in regional television studios; they may work in television organisations of Astana, Almaty, various regions of Russia, and creative teams of competitors. After authors of popular programmes leave ("Reaktsiya" Shibarshin), their programmes disappear from the air too. A proper substitute has not been found, and the deficiency of bright workers, professionals, educated intellectual specialists also made an impact (Zhussupova, 2011).

Television mastery is first of all a special life attitude, a way of living, constant accustoming to all spheres of public activity. Under the condition of deficiency of professional workers and an excessive workload of journalists of local channels working in the mode of real-time news, making plots for informative programmes daily, training of professional reporters and reviewers as speciality of students, future journalists in educational institutions might partially solve the problem. A proper curriculum will be worked out for this purpose.

\section{Discussions}

\subsection{Historical Excursion Problems}

Establishment of state television in Kazakhstan happens in a state of an aggressive advance of foreign television, commercial channels and cable TV networks on Kazakhstan information market. Furthermore, it is important to make effective management actual as a directing component that encourages the formation and qualitative development of state television. In the light of the recent events in the economic perspective of Kazakhstan, a notion of "innovative" character of the editorial manager would sound up-to-date. Innovative (according to P. Drucker, entrepreneurial) character of the manager activity suggests directivity at constant search of new diverse ways of activity organisation.

In Kazakhstan, there is a process of radical reappraisal, and journalists are active accomplices and, to a certain extent, the creators of this process. Media are also experiencing the same troubles as the whole of society. Today, 
Kazakhstan is a search of a new relationship between the state, society and the media, because the old models are already exhausted (Gurzhy et al., 2012). There is no doubt that such large projects, as construction of a new capital, strongly stimulate everything that is touched by human mind or hands. This happened to the development of regional TV and radio broadcasting. We have transferred from the stage of quantitative growth of new developing electronic channels to the stage of comprehension of the problems of formation of qualitative journalism. The experience of "Astana" TV channel shows that there are strengths, intelligence and talent to create such an interesting television and convinces us that bilingualism is not a "barrier" for commercial interest of private non-governmental channels and that programmes in the Kazakh language are not unattractive for advertisers, etc. Appearance of this channel on Kazakhstan information market is a big step towards qualitative, not "popular" television. This comes to mind not only because you like the creativity of journalists, but first of all because the work of programmes' presenters, directors, and designers confirms that "the package" of programmes with good execution, modern designer ideas, cut-ins, camera reports, etc. gives a special non-standard stylistics to the channel. We think that informational practice of "Astana" TV channel could be better studied, and the experience of managers of this TV organisation should be generalised. As for sharing this experience, it is more difficult to say something definite as it is the sphere of professional interests of competitors, partners, colleagues, etc. Still, the most important thing is on the surface: "Astana" has enlarged the circle of the mass media that has deserved respect of not only their viewers, readers, listeners, but also their colleagues from various regions of our country. As we can see from the distance, the capital television organisation worked out integral requirements that encourage professional growth of a journalist. Surprisingly, they stem from simple creative tasks: building the plot of a programme based on life experience, development of heroes' characters, objective reflection of events, and creation of compositionally interesting stories.

The partisan of impromptu and improvisation in reporting, Kazakhstan scientist and journalist M. Barmankulov in his famous book "Television: money or power?" defines the differences of newspaper and television reporting and pointed out underlying meaning of publicist creativity of a television journalist: "...the moment of journalist creativity coincides with the event itself. Life creativity should be followed by its creative comprehension by a publicist. They should immediately estimate the event, define its place in the row of other phenomena, give their value, lead their TV and radio audience. They should be prepared. But it should be the preparation for impromptu which is not expressed in written draft or adjustment to the event or its adaptation; it should be expressed in inner preparation and objective immediate estimation of an event" (Barmankulov, 1997).

\subsection{Problems Creative Skills}

The globalization of the media highlights the issue of equal access for all peoples to information. Scientists around the world continue to debate how to interpret the process of globalization of mass media and how it will be fruitful for the peripheral countries. In this regard, the expansion of the technical capabilities of a benefit or harm if it threatens public safety as a whole and individual countries in particular, because the leadership of technologically advanced countries over others creates unequal opportunities for the development of an information space in the world. Modern environment is still not able to support equal opportunities for all countries. (Strovsky, 2014)

So, what influences the channel rating? Every top manager has their own views, concepts and opinions concerning this issue, but it are well-known that the best TV programmes are those that are made on the basis of good imagination, not big money. The audience do not stand falsehood, they can react to properly structured creative work. Kostanay residents remember such programmes as "Povorot", "Reaktsiya", "Obratnaya svyaz" (TV and radio broadcasting company "Alau"); the stylistics of their texts was submitted to one universal rule: "Explain the difficult things simply". The analysis of economic, political issues, the results of journalist investigations of social conflicts were presented in a way which would be clear for both an academician and a pensioner. This is not an intentional "simplification", this is "decipherment" and possibility to present author's attitude to the current fact, event, it may be ironical. It is this light irony - and irony itself - that distinguished the plots of correspondents of the programme "Povorot" and others. For example, how to explain to people what cluster is if even scientists cannot do it? But the task of the correspondent is to achieve this by means of using particular approaches. The author of the plot referred to lexical and literary means of the Russian language. Cluster, an economically profitable way of maintaining the production of definite types of goods, products, service, is shown in comparison with an exotic plant that is transported in a pot from abroad and is cultivated in Kazakhstan soil. Not only was it demonstrated in an original way, but also shown in a non-standard way in a plot by Olga Yeryomkina about "dairy cluster". In a plot about problems of Kushmurun coal minefield, with the purpose to attract viewers' and mostly local authorities' attention, the so called "pseudo biblical" style was used: "There was a mine. And a quinquennium of chaos in the mine. Despair. Inactivity. Impecuniosity." ("Povorot"). Such a beginning immediately "catches" the viewer and warns - "what happens next?" and the plot is memorable. 
The combination of imaginative perception of the event with a particular stylistic choice of TV language is the feature that distinguishes a TV reporter from a newspaper reporter and radio journalist. For more expression, metaphorical and phraseological constructions were used, such as (not to turn a hair), (wait for manna). Furthermore, authors of texts often construct a symbiosis of idioms and comparisons turning them into puns: "It's no good turning back a pound", or "Akim helps those who help themselves". All these linguistic devices make the plot and the whole programme interesting.

One of the issues specific for North Kazakhstan TV journalism is the absence of interregional cooperation, inner contacts of TV and radio companies. Consolidation of joint efforts to solve common problems, for instance, organisation of regional creative competitions of TV journalists directed at realisation of encouraging ideas and creative potential of young journalists, might promote young and experienced TV journalists to new professional heights. A professional competition or festival for regional journalists that is independent from administrative resources of local authorities is really necessary to inspire a creative thought, "not to stagnate", and not to overuse stylistic clichés and the same ideas in journalist devices and techniques. Annual rewards for correspondents of newspapers, television and radio on Day of Kazakhstan journalism by regional and district authorities, representatives of regional business, managers of large industrial and agricultural enterprises, public organisations make regional journalism "handheld". These rewards are based on loyalty to the current policy and large business, not on creative achievements.

\subsection{Specificity of the Modern Information Environment}

Collaborative creative projects of electronic mass media in the region are a rare phenomenon, almost absent. Republican television organisations conduct many co-operative events the informative sponsors of which are several TV channels and studios. For example, "Khabar", "31 channel", NTK "Kazakhstan" are often mentioned as informative sponsors for various creative evenings and concerts, annual festivals "Alma-Ata meets friends", etc.

To attract the audience and survive economically, local news as the most demanded type of programme on regional and local TV must correspond with the criteria of sensational, operative, social journalism. "Handheld" journalism cannot be demanded; or rather demanded but for the definite group of people concerned. Social journalism causes respect to creativity of journalists since it is open for communication, available because it is honest and tells about problems of people, ordinary residents of the region, city, district, etc. "Many studies show that viewers expect "a positive life model" from local informative programmes that encourages consolidation of regional identity. Nevertheless, it often leads to loyalist attitude to local authorities, to the absence of analytics and constructive criticism on the air which causes unification of regional TV journalism" (Journalism on the crossroads: experience of Russia and the USA, 2006.).

"The most popular and famous" journalist, in their own opinion, is quite a widespread form of ambition which is followed by replacement of the image of a really authoritative person on television. Popularity of a journalist or presenter is not defined by serious sociological research of independent companies. We think the research made by professional agencies the function of which would be the study of real condition of television informative market: the rating of channels, programmes, cycle shows and people separately - might stimulate journalist creativity. Small measurements made periodically cannot give an objective value. As a rule, they do not have comparative and contrastive characteristics; the viewers actually obtain the information which TV and radio companies that organised the research and provided financial support are interested in, therefore, the population survey results are often predictable. But their objectivity is doubtful.

Serious competition for advertising profits between regional TV and radio stations (if there are several of them in the region) objectified the problem of professionalism of advertising managers, salesmen (advertising agents); specialists that are qualified and knowledgeable in marketing and television are more demanded. Without this, there is no successful sale of television time at all as TV and radio companies interested in the own self-sustainability must be aware of all changes of advertising market, characteristics of advertising customers, clients, target consumers so that they might sell more audio-visual goods and service.

Western researchers of television management recommend the system of various compensations (salary plus bonus as a contrast to commission) to create necessary stimulus for advertising agents and other personnel for increasing profits from sale of advertising time. Managers of small regional TV stations constantly have to compete for advertising profits with other mass media (newspapers and radio), so they must be encouraged for successful work.

A well-known businessman in Kazakhstan, a successful media manager Armanzhan Baitasov about modern information space says: "I as a citizen said that in our country is lack of information. We lose its information 
field in relation to other media ... We have own Kazakhstan school of journalism, their own country. Can create and its information field. I believe that we need to do something and not just sit back and reap the dividends " (Baitasov, 2014). Unfortunately, local TV studios do not show interest in organisation of their own public relations service. In the author's opinion, this is a substantial disadvantage of television management of not only the specific type of business, but also of the social institute of a developing civil society.

\subsection{Touches Media Management and Media Education}

In the study of the experience of TV studios management of northern regions of Kazakhstan, the author has not defined any distinct systematic strategic plans for increasing creative motivation of journalists and other television workers either. It is known that the satisfied need in the practice of journalist creativity motivates and determines the behaviour of people. In this context, theories of famous foreign scientists (Maslow, Vroom, D. McGregor, etc.) about the problem of motivation deserve attention. There is no doubt that for a creative person, aspiration for success and career is one of the most important needs of workers. It defines their readiness for conscientious and effective work, inclination for critical and accurate estimate of the achieved progress as "the one who can rely on strong people always turns out to be strong. It is much more difficult than to roll in success. But it is much more profitable in the context of professional growth" (Zvereva, 2004). Within the work team, where it is difficult to satisfy diverse needs of all employees - journalists can be referred to this category, an important task of creative management is the development of a certain employee's need that is most necessary for informative publicist activity. Compliance of individual needs with the needs of all creative team most definitely increases the effectiveness of collective labour. But in practice, to achieve this is difficult as "many sociological studies showed that most workers do not want to be "pebbles on the beach". They want to participate in management decision-making, to have many-sided social communication, friendly support, respect" (Govorova, 2003). A modern journalist understands clearly that with the increase in requirements for journalist mastery and activation of creative potential, they have more reasons for changing motivation, determined by conditions of satisfaction of professional and personal needs. If there are common editorial purposes and principles of journalist activity, internal stimuli switch on which often become more effective than external ones (administrative, disciplinary).

The role of the "observer" is a strong natural support in constantly test the information needs of the public and society, and in the tradition of the press itself. The role of the critic ... or "watchdog" can no longer be encouraged medialogikoy than the logic of objective facts posts. Information continues to be the essence of the role of journalism, and it's something that the profession (or craft) learned to do best ... Having weighed everything, it can be concluded that in some versions of the role of the "observer" is widely recognized as the standard to which should be sought. This recognition is reflected in the aspirations and views of journalists and often- wider audience. This is confirmed by the apparent similarity of the genre of news in a variety of political and media systems (McQuail, 2013).

Undoubted feature of television today: multi-channel, the use of different methods of television communication, variety of genres of television programs, the possibility of creative realization of the most incredible projects, the presence of a large number of expressive means and methods of their use. (Gurzhy et al., 2012). Creative television management as practice of directing informative activity of a group of people is aimed at motivating for realisation of creative tasks by means of technological development of creation of spectacular informative opinion journalism. On the other hand, management of modern regional television is not limited to creative tasks and ideas - it exists on basic principles of business and rules of civilised business organisation. International expert on media Mathew Ingram and notices of the once great popularity of traditional media and the competition between them and the new media, but even now, their perspective on that competition may still be too narrow they are competing with anything that captures a reader's attention. Mathew Ingram claims that (I would argue that they are competing with any service that fills an information need) (Ingram, 2014).

\section{Conclusions}

The defined signs of the development of information management in the regional television journalism allow stating certain recommendations that might bring about qualitative changes in the activity of regional electronic media:

1) For more effective and efficient activity of managers, conduct seminars, courses for training and re-training of specialists in the field of management and marketing of electronic media. Thus, you will encourage the formation of national, i.e., Kazakhstan school of television managers and journalists with new economic thinking (Zhussupova, 2010).

2) For development of state television as a public institute and subject of the region economy, a more active 
advance and popularisation of their information policy are necessary. State television is not able to resist monopoly of private media, cable networks, and expansion of foreign TV independently, without increasing subsidies.

3) Programming of a regional TV channel, including a state one, is to be conducted on the basis of sociological research, study of consumer interests. There arises a need to create independent sociological service on professional basis, PR-agencies that would constantly and efficiently study the audience, carry out public relations.

4) The issue of organisation of educational structures concerning training of PR specialists is made actual. Professionalism of public relations (PR) as in the entire media management is also directed at approaching the time of competitive Kazakhstan regional television.

5) While studying the position of modern media management, a special attention should be paid to human factor as the resource of TV business. It is reasonable to consider the issue of creation of study centres at faculties of journalism at universities the chief task of which would be to improve professional mastery of practicing journalists, to acquire modern standards of information activity, media management and media economics.

Nevertheless, the majority of respondents agree that the demand calls for a review of its programs and their reorientation to new digital editions profession converged... for Achieve these goals, the school should create and maintain a modern infrastructure and technical facilities, install new computers and software, to use cloud technology, and train qualified trainers who regularly update their professional competence (Vartanova \& Lukina, 2014). In Kazakhstan, the attempts to study management on television, particularly its practical aspect, have begun since the mid-90-s of the XXth century. Later, in Al-Farabi KazNU the department of Media Management was opened, which demonstrates the interest in training journalists of a new market formation. Nevertheless, some regional television studios need help in acquiring market technology, all the more, life never stops, always changes. As our analysis shows, the need in journalists who can combine knowledge in the field of opinion journalism, economics, organisation and team management is on the rise. The necessity to study television management as a separate branch of science is especially noticeable on the regional level where the absence of specialists professionally prepared in this field impacts the general business condition of the mass media.

The history of the media management is not so long. It is a comparatively new direction in journalism study that means generalisation of a peculiar system of relationships both inside a creative organisation and outside of it, justification of the principles of a successful development of a media enterprise. Management sets relationships in a team that encourage realisation of personal potential, perfection of professional skills of a television editorial worker, creation of TV programmes that are able to get profit and satisfy the needs of mass audience in the information product. The importance of professional media management is obvious (Vartanova et al., 2006). Successful functioning and achievement of the set aims and tasks of a creative organisation depend on competitiveness, wisdom and resourcefulness of a manager and each employee of the editorial team.

\section{Acknowledgements}

Article made under grants from the Ministry of Education and Science of the Republic of Kazakhstan:

1) According to the budget program 055 "Scientific and / or technical activities", the routine 101 "Grant funding for research", by priority: "The intellectual potential of the country," Theme "Specificity of formation of modern regional media market as the intellectual potential of the country", Grant from the Ministry of Education and Science of the Republic of Kazakhstan (2012-2014гг.);

2) "The best teacher of the university," according to the results of 2013. Grant from the Ministry of Education and Science of the Republic of Kazakhstan.

Grateful to the students of specialty "journalism" and colleagues Kostanay State University for helps and support in the implementation of research projects.

\section{References}

Akhmetova, L. S. (2000). Journalism and management: Study guide (p. 131). Almaty: Kazak universities.

Barmankulov, M. K. (1997). Television: Money or power: Study guide (p. 272). Almaty: Sanat.

Denis, M. (2013). Journalism and Society (p. 368). Translated from English. M.: Mediamir; Faculty of Journalism of Moscow State University Lomonosov Moscow State University. 
Dzyaloshinsky, J. M. (2014). Russian mass media prospects for transformation (pp. 77-105). In World of Media Yearbook of Russian Media and Journalism Studies. M.: Lomonosov State Universaty, My World, 2014. $280 \mathrm{c}$.

Govorova, N. A. (2003). Topical problems of personnel policy: Strategic and practical tasks in systematic management of personnel, involvement, selection and consolidation of employees. Retrieved from http://sbiblio.com/biblio/archive/govorova_actual_problem/?search=\%e3\%ee\%e2\%ee\%f0\%ee\%e2\%e0\#st

Gurzhy, T. M., Baymolda, D., \& Shevyakova, T. V. (2012). Television of the Republic of Kazakhstan: A manual for schools (p. 80). Almaty KazNPU. Abaya.

Informational and analytical portal 365info.kz. (2014). Kazakhstan should look Ukrainian news, convinced millionaire Baitasov. Retrieved October 13, 2014, from http://365info.kz/2014/10/kazaxstanu-nuzhnosmotret-ukrainskie-novosti-ubezhden-millioner/

Ingram, M. (2014). Journalism's biggest competitors are things that don't even look like journalism. Retrieved from https://gigaom.com/2014/10/10/journalism-biggest-competitors-are-things-that-dont-even-look-likejournalism/

Jackson, C., Grayson, Jr., \& O'Dell, C. (2001). American management at the turn of the $21^{\text {st }}$ century. Retrieved from http://sbiblio.com/biblio/archive/jekson_amerikmenej/?search=\%e3\%f0\%e $5 \% \mathrm{e} 9 \% \mathrm{fl} \% \mathrm{ee} \% \mathrm{ed \# st}$

Kevin, G. B. (2013). Journalism. Retrieved March 14, 2013, from http://jou.sagepub.com/content/14/1/3

Ross, K., Evans, E., Harrison, L., Shears, M., \& Wadia, K. (2013). The Gender of News and News of Gender: A Study of Sex, Politics, and Press Coverage of the 2010 British General Election. Retrieved March 18, 2013, from http://hij.sagepub.com/content/18/1/3

Scherbina, V. V. (2003). The problem of management in the sphere of human resources management. Sociological research, 7, 58.

Strovsky, D. (2014). Media Globalization and Its Influence on National Communities: Evaluating M. McLuhan's Concept Today (pp. 9-38). In E. L. Vartanova (Ed.), World of Media Yearbook of Russian Media and Journalism Studies (p. 280). M.: Lomonosov State University, My World, 2014.

Vartanova, E. L., \& Lukina, M. M. (2014). New competences for future journalists: Russian journalism education executives evaluate industrial demand (pp. 209-232). World of Media Yearbook of Russian Media and Journalism Studies. M.: lomonosov State Universaty, My World, 2014. 280 c.

Vartanova, Y. L. (2003). Media economics of foreign countries: Study guide (p. 335). M.: Aspekt press.

Vartanova, Y. L. (2006). Journalism on the crossroads: Experience of Russia and the USA (p. 184). M.: Mediamir.

Vartanova, Y. L., Gutova, M. I., \& Ivanitsky, V. L. (2006). In Y. L. Vartanova (Ed.), Encyclopaedia of world industry of the mass media: Study guide for university students (p. 376). M.: Aspekt Press.

Zhussupova, A. M. (2010). Modeling of effective management in regional television. Treasury Bulletin Series journalism, Almaty, 2(28), 129-132.

Zhussupova, A. M. (2011). Problems activating the creative capacity of the journalist (pp. 222-225). Realities and prospects of innovative development of science and education in Kazakhstan: International scientific and practical conference "Baytursynov read -2011." April 14, 2011. Kostanay. KSU named A. Baitursynov.

Zvereva, N. V. (2004). School of regional television journalist: Study guide (p. 320). M.: Aspekt Press.

\section{Copyrights}

Copyright for this article is retained by the author(s), with first publication rights granted to the journal.

This is an open-access article distributed under the terms and conditions of the Creative Commons Attribution license (http://creativecommons.org/licenses/by/3.0/). 